Atmos. Chem. Phys., 17, 15007-15017, 2017

https://doi.org/10.5194/acp-17-15007-2017

(C) Author(s) 2017. This work is distributed under

the Creative Commons Attribution 4.0 License.

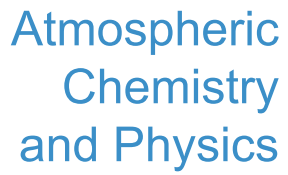

(c) (P)

\title{
Quantification of an atmospheric nucleation and growth process as a single source of aerosol particles in a city
}

\author{
Imre Salma, Veronika Varga, and Zoltán Németh \\ Institute of Chemistry, Eötvös University, 1518 Budapest, P.O. Box 32, Hungary \\ Correspondence: Imre Salma (salma@ chem.elte.hu)
}

Received: 31 August 2017 - Discussion started: 27 September 2017

Revised: 27 November 2017 - Accepted: 10 December 2017 - Published: 19 December 2017

\begin{abstract}
Effects of a new aerosol particle formation (NPF) and particle diameter growth process as a single source of atmospheric particle number concentrations were evaluated and quantified on the basis of experimental data sets obtained from particle number size distribution measurements in the city centre and near-city background of Budapest for 5 years. Nucleation strength factors for a nucleation day $\left(\mathrm{NSF}_{\mathrm{NUC}}\right)$ and for a general day $\left(\mathrm{NSF}_{\mathrm{GEN}}\right)$ were derived separately for seasons and full years. The former characteristic represents the concentration increment of ultrafine (UF) particles specifically on nucleation days with respect to accumulationmode (regional background) concentrations (particles with equivalent diameters of $\left.100-1000 \mathrm{~nm} ; N_{100-1000}\right)$ due solely to the nucleation process. The latter factor expresses the contribution of nucleation to particle numbers on general days; thus, it represents a longer time interval such as season or year. The nucleation source had the largest effect on the concentrations around noon and early afternoon, as expected. During this time interval, it became the major source of particles in the near-city background. Nucleation increased the daily mean concentrations on nucleation days by mean factors of 2.3 and 1.58 in the near-city background and city centre, respectively. Its effect was largest in winter, which was explained by the substantially lower $N_{100-1000}$ levels on nucleation days than those on non-nucleation days. On an annual timescale, $37 \%$ of the UF particles were generated by nucleation in the near-city background, while NPF produced $13 \%$ of UF particles in the city centre. The differences among the annual mean values, and among the corresponding seasonal mean values, were likely caused by the variability in controlling factors from year to year. The values obtained represent the lower limits of the contributions. The shares determined imply that NPF is a non-negligible or substan-
\end{abstract}

tial source of particles in near-city background environments and even in city centres, where the vehicular road emissions usually prevail. Atmospheric residence time of nucleationmode particles was assessed by a decay curve analysis, and a mean of 02:30 was obtained. The present study suggests that the health-related consequences of the atmospheric NPF and growth process in cities should also be considered in addition to its urban climate implications.

\section{Introduction}

Large-scale modelling studies suggest that the new aerosol particle formation (NPF) and consecutive particle diameter growth process in the atmosphere (Kulmala et al., 2004, 2013 ) is the dominant source of particle number concentrations on a global scale (Spracklen et al., 2006; Reddington et al., 2011; Makkonen et al., 2012; Yu et al., 2015). In addition, up to approximately $50 \%$ of all cloud condensation nuclei $(\mathrm{CCN})$ can originate from NPF and growth (Spracklen et al., 2008; Merikanto et al., 2009), which relates the process to the climate system and indicates its overall importance (Kerminen et al., 2012; Carslaw et al., 2013; Shen et al., 2017). New particle formation has also been proven to be common in large cities (Nieminen et al., 2017). Urban NPF can interact with and can be influenced by regional nucleation events, at least under some geographic conditions, and can become part of a phenomenon with a much larger horizontal extension than the city (Salma et al., 2016b). At the same time, particle number concentrations in cities are strongly affected by high-temperature emission sources from different sectors (Paasonen et al., 2016) such as household and residential heating (e.g. Butt et al., 2016), industrial pro- 
cesses and power production (e.g. Xiao et al., 2015), and vehicular road traffic (e.g. Morawska et al., 2008). Their diurnal variation often shows daily time-activity patterns of inhabitants (Dall'Osto et al., 2013). Relative contributions of primary and secondary particle sources - particularly in cities - change substantially in time and space (Pikridas et al., 2015; Posner and Pandis, 2015). Several methods were proposed to distinguish the major production types of particles (e.g. Shi et al., 1999; Alam et al., 2003; Rodrígues and Cuevas, 2007; Qian et al., 2007; Park et al., 2008; Costabile et al., 2009; Brines et al., 2015). The share of NPF as a single source of ambient particle number concentrations specifically in cities remained, however, largely unknown despite the fact that there is often a spatial coincidence between the poorer air quality and population density (Samoli et al., 2016). Moreover, approximately $70-80 \%$ of total particles in cities belong to the ultrafine (UF) size range (with an equivalent diameter of $<100 \mathrm{~nm}$; Putaud et al., 2010), and their inhalation can represent an excess health risk relative to coarse or fine particles with the same or similar chemical composition (Oberdörster et al., 2005; Braakhuis et al., 2014). An estimate of the relative contribution of primary and secondary formation processes is also required for efficient action plans to improve the air quality in cities. It is worth noting that indirect climate effects (due to $\mathrm{CCN}$ ) become important for particles with diameters $>50-100 \mathrm{~nm}$, while the excess health effects are linked to diameters $<100 \mathrm{~nm}$.

The nucleation strength factor (NSF) was introduced to assess the contribution of NPF to UF particle number concentrations relative to accumulation-mode (regional background) concentration (represented by particles with diameters of $\left.100-1000 \mathrm{~nm} ; N_{100-1000}\right)$ with respect to all other sources (Salma et al., 2014). The results derived from this approach correspond to the mode-segregated secondary particle load. By now, atmospheric concentration data sets are available for multiple years to study the applicability, behaviour and interpretation of the NSF in detail. The major advantage of this quantification approach is that it only requires experimental data that can be readily derived from ordinary NPF (size distribution) measurements. The main objectives of this paper are to quantify and discuss the contribution of NPF events to ambient particle number concentrations in near-city and central urban environments of a central European city considering 5-year long data sets, to investigate and explain the meaning and further details of the NSF, and to interpret the consequences achieved for the urban air and air quality.

\section{Methods}

\subsection{Experimental}

The measurements were performed in Budapest, Hungary. Its population is approximately 2.5 million in the metropoli$\tan$ area. The major pollution sources in terms of particle number include vehicular road traffic, residential heating and household burning activities. Contributions of passenger cars and buses to the vehicle fleet registered in Budapest and Pest County are 87 and $0.46 \%$, respectively (OKJ, 2015). Dieselpowered vehicles contributed 19 and $97 \%$ of the national passenger car and bus fleets, respectively. Wintertime median concentrations of particulate matter (PM) mass, elemental carbon (EC) and organic carbon (OC) in the $\mathrm{PM}_{2.5}$ size fraction were $25,0.97$ and $4.9 \mathrm{\mu g} \mathrm{m}^{-3}$, respectively, in the related time interval (Salma et al., 2017). The mean contributions of $\mathrm{EC}$ and organic matter (OM, with an OM / OC mass conversion factor of 1.6) to the $\mathrm{PM}_{2.5}$ mass and standard deviation (SD) were $4.8 \pm 2.1$ and $37 \pm 10 \%$, respectively, while the contributions of $\left(\mathrm{NH}_{4}\right)_{2} \mathrm{SO}_{4}$ and $\mathrm{NH}_{4} \mathrm{NO}_{3}$ derived from an earlier study in spring were 24 and $3 \%$, respectively. The contributions of EC and OC from fossil fuel combustion to the total carbon contained in particles $(\mathrm{TC}=\mathrm{OC}+\mathrm{EC})$ were 11.0 and $25 \%$, respectively, and $\mathrm{EC}$ and $\mathrm{OC}$ from biomass burning were responsible for 5.8 and $34 \%$, respectively, of the TC, while the OC from biogenic sources made up $24 \%$ of the TC.

Two urban sites were involved in the study. Most measurements were performed at the Budapest platform for Aerosol Research and Training (BpART) facility of Eötvös University $\left(47^{\circ} 28^{\prime} 29.9^{\prime \prime} \mathrm{N}, 19^{\circ} 3^{\prime} 44.6^{\prime \prime} \mathrm{E}\right), 115 \mathrm{~m}$ above mean sea level (a.s.l.) (Salma et al., 2016a). The sampling inlets were set up at heights between 12 and $13 \mathrm{~m}$ above the street level. The location represents a well-mixed, average atmospheric environment for the city centre. The other location was situated at the north-western border of Budapest in a wooded area of the Konkoly Astronomical Observatory of the Hungarian Academy of Sciences $\left(47^{\circ} 30^{\prime} 00.0^{\prime \prime} \mathrm{N}, 18^{\circ} 57^{\prime} 46.8^{\prime \prime} \mathrm{E}\right.$; $478 \mathrm{~m}$ a.s.l.). It represents the air masses entering the city since the prevailing wind direction in the area is northwesterly. The experimental data obtained for 5 full year long time intervals, i.e. from 3 November 2008 to 2 November 2009, from 19 January 2012 to 18 January 2013, from 13 November 2013 to 12 November 2014, from 13 November 2014 to 12 November 2015 and from 13 November 2015 to 12 November 2016 were considered in the present study. Local time (UTC +1 , and daylight savings time, UTC +2 ) was chosen as the timescale because the daily routine activities of the inhabitants in the city were primarily considered.

The key measuring instrument was a flow-switching type differential mobility particle sizer (DMPS; Salma et al., 2011). Its main components include a Ni-60 radioactive bipolar charger, a Nafion semi-permeable membrane dryer, a $28 \mathrm{~cm}$ long Vienna-type differential mobility analyser and a butanol-based condensation particle counter (TSI, model 3775). The system operates in an electrical mobility diameter range from 6 to $1000 \mathrm{~nm}$ in the dry state of particles (with a relative humidity of $\mathrm{RH}<30 \%$ ) in 30 channels with a time resolution of approximately 8 or $10 \mathrm{~min}$ at two sets of flows. The sample flow rate is $2.0 \mathrm{~L} \mathrm{~min}^{-1}$ in high-flow mode, and $0.31 \mathrm{~L} \mathrm{~min}^{-1}$ in low-flow mode with sheath air 
flow rates 10 times larger than for the sample flows. The DMPS measurements were performed according to the international technical standard (Wiedensohler et al., 2012). The DMPS data for the 1-year long time intervals in 20082009, 2012-2013, 2013-2014, 2014-2015 and 2015-2016 were available in $95,95,99,95$ and $73 \%$ of the total number of days, respectively. Meteorological data were recorded by an on-site meteorological station (Salma et al., 2016a). Standardized meteorological measurements of air temperature $(T), \mathrm{RH}$, wind speed and wind direction were recorded with a time resolution of $10 \mathrm{~min}$. The coverage of the meteorological data was $>80 \%$ in each year.

\subsection{Data treatment}

The overall treatment of the measured DMPS data was performed according to the procedure protocol by Kulmala et al. (2012). The inverted DMPS data were utilized to generate particle number size distribution surface plots showing jointly the variation in particle diameter and particle number concentration density in time. Identification and classification of NPF and growth events were accomplished from the surface plots by using an algorithm similar to that of Dal Maso et al. (2005) on a day-to-day basis in the following main classes: NPF event days, non-event days, days with undefined character, and days with missing data (for more than $4 \mathrm{~h}$ in the midday). Frequency of events was determined as the ratio of the number of event days to the total number of relevant (i.e. all-missing) days. Particle number concentrations in the diameter ranges from 6 to $1000 \mathrm{~nm}\left(N_{6-1000}\right)$, from 6 to $100 \mathrm{~nm}\left(N_{6-100}\right)$, from 6 to $25 \mathrm{~nm}\left(N_{6-25}\right)$ and from 100 to $1000 \mathrm{~nm}\left(N_{100-1000}\right)$ were calculated from the DMPS data. The major portion of the $N_{6-100}$ concentration (i.e. in the Aitken mode plus sporadically the nucleation mode) is essentially related to local source processes due to the limited atmospheric residence time (typically $<10^{1} \mathrm{~h}$ ) of these particles, while $N_{100-1000}$ (regional background concentration associated mainly with the accumulation mode) expresses larger spatial scales and timescales because of much longer residence times (up to $10^{1} \mathrm{~d}$; Salma et al., 2011). To obtain the mean diurnal variation of the concentrations and further properties derived from them (see later), the exact recording times belonging to the individual concentrations were rounded off to $5 \mathrm{~min}$ (in the case of the time resolution of ca. $8 \mathrm{~min}$ ) or $10 \mathrm{~min}$ (in the case of the time resolution of ca. $10 \mathrm{~min}$ ) timescales. These data were averaged by the time of day separately for nucleation and non-nucleation days. Finally, the averaging was also performed separately for different seasons, i.e. for spring (March-May), summer (June-August), autumn (September-November) and winter (December-February), and for the measurement year.
Two types of NSF (Salma et al., 2014) were derived in the present study by considering different conditions. The quantity

$\mathrm{NSF}_{\text {NUC }}=\frac{\left(\frac{N_{6-100}}{N_{100-1000}}\right)_{\text {nucleation days }}}{\left(\frac{N_{6-100}}{N_{100-1000}}\right)_{\text {non-nucleation days }}}$

considers the $N_{6-100} / N_{100-1000}$ concentration ratios for nucleation days only. The numerator expresses the increase in $N_{6-100}$ relative to the $N_{100-1000}$ caused by all the sources. The denominator represents the same property due to all the sources except for NPF. Hence, $\mathrm{NSF}_{\mathrm{NUC}}$ accounts for the concentration increment on a nucleation day exclusively caused by NPF. It was implicitly assumed that the major emission and formation processes of UF particles except for NPF are uniformly present on both nucleation and nonnucleation days. It seems to be a reasonable condition for time intervals of several months, although the number of nucleation days during a time interval actually plays a more determining role than the length of the time interval. Winter, when the occurrence frequency shows the minimum (see Table 1), appears to be the most restrictive or critical season. The effect of the non-uniformly present sources is indicated by unusually large scatter in the diurnal data points (see Sect. 3.2). It was also presumed that the production of particles larger than $100 \mathrm{~nm}$ was much smaller than the concentration of UF particles. This is ordinarily realized in cities, and can be justified from the contributions of UF particles to the total particle number (Putaud et al., 2010; Németh et al., 2017).

The other type of NSF was calculated for all days in the numerator, i.e.

$\mathrm{NSF}_{\mathrm{GEN}}=\frac{\left(\frac{N_{6-100}}{N_{100-1000}}\right)_{\text {all days }}}{\left(\frac{N_{6-100}}{N_{100-1000}}\right)_{\text {non-nucleation days }}}$.

It expresses the overall contribution of NPF to $N_{100-1000}$ on a longer time span, i.e. in general. Since there are usually more non-nucleation days than nucleation days in a time interval of a month or more (Nieminen et al., 2017), the assumptions for $\mathrm{NSF}_{\mathrm{GEN}}$ are met more easily than for $\mathrm{NSF}_{\mathrm{NUC}}$. $\mathrm{NSF}_{\mathrm{NUC}}$ characterizes an ordinary nucleation day within e.g. a season, while $\mathrm{NSF}_{\mathrm{GEN}}$ quantifies the overall effect of NPF and growth on the atmospheric concentrations on a regular/average day over e.g. a season or year. The former is always larger than the latter due to their definition. They can be calculated for seasons or years. Despite their relatively simple mathematical definition, the exact meaning and rigorous interpretation of $\mathrm{NSF}_{\mathrm{NUC}}$ and $\mathrm{NSF}_{\mathrm{GEN}}$ are complex, and they should be approached with care, in particular as far as the assumptions about their utilization are concerned. If (1) $\mathrm{NSF} \approx 1$, then the relative contribution of nucleation to particle number concentrations with respect to other sources 
Table 1. Number of nucleation days for seasons in the near-city background (in 2012-2013) and in the city centre (in 2008-2009, 2013-2014, 2014-2015 and 2015-2016) during 1-year long time intervals.

\begin{tabular}{llrrrr}
\hline Environment & $\begin{array}{l}\text { Time } \\
\text { interval }\end{array}$ & Spring & Summer & Autumn & Winter \\
\hline Background & $2012-2013$ & 35 & 20 & 24 & 17 \\
Centre & $2008-2009$ & 34 & 21 & 22 & 6 \\
Centre & $2013-2014$ & 28 & 20 & 13 & 11 \\
Centre & $2014-2015$ & 41 & 19 & 14 & 7 \\
Centre & $2015-2016$ & 15 & $9^{*}$ & $5^{*}$ & 6 \\
\hline
\end{tabular}

* Low data coverage. See Sect. 2.1

is negligible; if (2) $1<\mathrm{NSF}<2$, then its relative contribution as a single source is considerable; and if (3) $\mathrm{NSF}>2$, then the contribution of nucleation itself to particle number concentrations is larger than of any other source sectors together. The interpretation regarding the limiting values is valid for both types of NSF. Since the major phase of the NPF and growth process takes place in most cases in 1 day, it is advantageous to express NSFs as daily mean values. The data for the undefined days were not taken into account for the present evaluation.

\section{Results and discussion}

The number of nucleation days for different seasons in each measurement year are summarized in Table 1. It is seen that the NPF frequency has an obvious seasonal variation. This can be obtained from its monthly dependency, which exhibits an absolute and local minimum in January and August, respectively, and an absolute and local maximum in March or April, and September, respectively (Salma et al., 2016b). The seasonal variation of the nucleation frequency fits into the second group of measurement sites - which is characterized by the highest number of nucleation events in spring and the lowest in winter, with a relatively high total number of events (Manninen et al., 2010).

\subsection{Seasonal atmospheric concentrations}

Particle number concentrations in the related size fractions for different seasons in each measurement year are summarized in Table 2 for an overview.

Data coverage for summer and autumn in 2015-2016 was low, and, therefore, the corresponding concentration ratios were excluded from the averaging for the mean ratios. It can be seen that the $N_{6-100}$ were ordinarily larger on nucleation days than on non-nucleation days. This is most likely a direct effect of nucleation. At the same time, the $N_{100-1000}$ usually showed a constant level within approximately $10 \%$, except for the winters and some autumns. The $N_{100-1000}$ on nucleation days were, however, smaller (by factors of $0.4-$
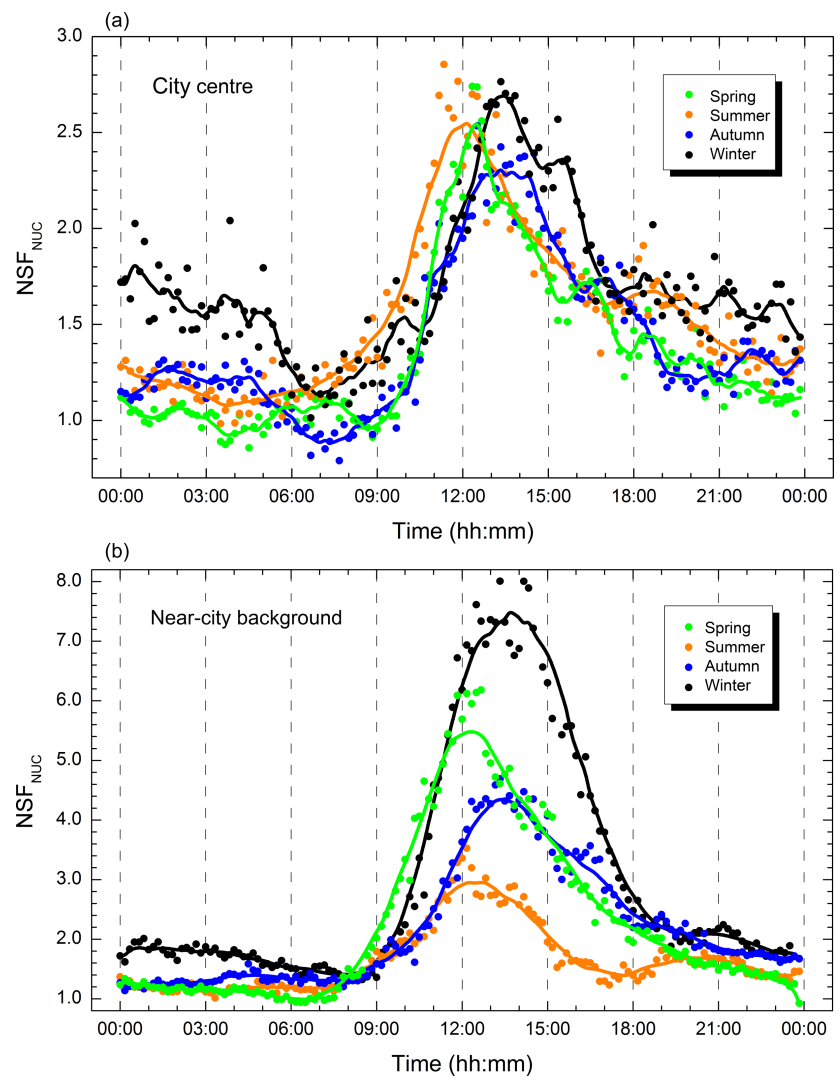

Figure 1. Diurnal variation of concentration increments on a nucleation day $\left(\mathrm{NSF}_{\mathrm{NUC}}\right)$ due to new particle formation and growth for the city centre in 2008-2009 (a) and in the near-city background in 2012-2013 (b) separately for seasons. The solid lines represent $1 \mathrm{~h}$ smoothing of the data.

$0.5)$ than for non-nucleation days, particularly in winter. The differences are further discussed and explained in Sect. 3.2.

\subsection{Concentration increment on a nucleation day}

Diurnal variations of the concentration increment due to NPF on a nucleation day (i.e. of $\mathrm{NSF}_{\mathrm{NUC}}$ ) for the city centre and near-city background separately for different seasons are shown in Fig. 1 as representative examples. The curves exhibited a single peak around noon with a longer tail on the decreasing side. The exact location of the peak is also influenced by setting the local daylight saving time in spring and autumn. The baseline of some peaks from 00:00 to 07:00 deviated systematically and substantially from unity, although no nocturnal nucleation has been observed in Budapest. The mean values of this baseline in the city centre for spring, summer, autumn and winter (Fig. 1a) were 1.02, 1.15, 1.15 and 1.55 , respectively, while they were $1.11,1.18,1.31$ and 1.72, respectively, in the near-city background (Fig. 1b). The elevated line can be explained by the fact that the particle growth process could be traced till the late morning of the next day on several occasions; thus, the NPF influenced the 
Table 2. Median atmospheric concentration of particles with diameters from 6 to $100 \mathrm{~nm}\left(N_{6-100}\right)$ and from 100 to $1000 \mathrm{~nm}\left(N_{100-1000}\right)$ in units of $10^{3} \mathrm{~cm}^{-3}$ separately on nucleation (Nuc) days and non-nucleation (Nonuc) days for seasons in the near-city background (in 2012-2013) and in the city centre (in 2008-2009, 2013-2014, 2014-2015 and 2015-2016) during 1-year long time intervals. Mean ratios of median concentrations on nucleation days to those on non-nucleation days with the standard deviation (SD) for the size fraction are also indicated.

\begin{tabular}{|c|c|c|c|c|c|c|c|c|c|}
\hline \multicolumn{3}{|c|}{ Urban environment } & \multicolumn{2}{|c|}{ Near-city backgr. } & \multicolumn{5}{|c|}{ City centre } \\
\hline $\begin{array}{l}\text { Time } \\
\text { interval }\end{array}$ & $\begin{array}{l}\text { Size } \\
\text { fraction }\end{array}$ & $\begin{array}{l}\text { Day } \\
\text { type }\end{array}$ & 2012-2013 & Ratio & 2008-2009 & 2013-2014 & 2014-2015 & 2015-2016 & Ratio \pm SD \\
\hline Spring & $\begin{array}{l}N_{6-100} \\
N_{6-100} \\
N_{100-1000} \\
N_{100-1000}\end{array}$ & $\begin{array}{l}\text { Nuc } \\
\text { Nonuc } \\
\text { Nuc } \\
\text { Nonuc }\end{array}$ & $\begin{array}{r}4.8 \\
2.8 \\
1.56 \\
1.51\end{array}$ & $\begin{array}{l}1.72 \\
1.03\end{array}$ & $\begin{array}{r}11.2 \\
8.9 \\
2.0 \\
2.2\end{array}$ & $\begin{array}{l}9.7 \\
7.2 \\
2.5 \\
2.7\end{array}$ & $\begin{array}{r}10.0 \\
7.1 \\
2.6 \\
2.5\end{array}$ & $\begin{array}{r}8.6 \\
5.9 \\
1.56 \\
1.5\end{array}$ & $\begin{array}{r}1.37 \\
\pm 0.09 \\
0.99 \\
\pm 0.07\end{array}$ \\
\hline Summer & $\begin{array}{l}N_{6-100} \\
N_{6-100} \\
N_{100-1000} \\
N_{100-1000}\end{array}$ & $\begin{array}{l}\text { Nuc } \\
\text { Nonuc } \\
\text { Nuc } \\
\text { Nonuc }\end{array}$ & $\begin{array}{r}4.0 \\
2.9 \\
1.27 \\
1.42\end{array}$ & $\begin{array}{l}1.37 \\
0.89\end{array}$ & $\begin{array}{r}10.3 \\
8.9 \\
1.36 \\
1.72\end{array}$ & $\begin{array}{l}8.0 \\
7.5 \\
2.0 \\
2.4\end{array}$ & $\begin{array}{l}8.6 \\
6.5 \\
2.5 \\
2.4\end{array}$ & $\begin{array}{r}6.9^{*} \\
6.2^{*} \\
1.40^{*} \\
1.37^{*}\end{array}$ & $\begin{array}{r}1.17 \\
\pm 0.11 \\
0.92 \\
\pm 0.13\end{array}$ \\
\hline Autumn & $\begin{array}{l}N_{6-100} \\
N_{6-100} \\
N_{100-1000} \\
N_{100-1000}\end{array}$ & $\begin{array}{l}\text { Nuc } \\
\text { Nonuc } \\
\text { Nuc } \\
\text { Nonuc }\end{array}$ & $\begin{array}{r}4.3 \\
3.3 \\
1.67 \\
2.3\end{array}$ & $\begin{array}{l}1.29 \\
0.74\end{array}$ & $\begin{array}{r}14.0 \\
10.4 \\
2.0 \\
2.4\end{array}$ & $\begin{array}{r}11.9 \\
8.5 \\
3.4 \\
3.9\end{array}$ & $\begin{array}{r}12.6 \\
8.4 \\
2.7 \\
3.3\end{array}$ & $\begin{array}{l}5.2^{*} \\
5.1^{*} \\
1.6^{*} \\
1.7^{*}\end{array}$ & $\begin{array}{r}1.41 \\
\pm 0.08 \\
0.87 \\
\pm 0.06\end{array}$ \\
\hline Winter & $\begin{array}{l}N_{6-100} \\
N_{6-100} \\
N_{100-1000} \\
N_{100-1000}\end{array}$ & $\begin{array}{l}\text { Nuc } \\
\text { Nonuc } \\
\text { Nuc } \\
\text { Nonuc }\end{array}$ & $\begin{array}{r}3.9 \\
3.6 \\
1.12 \\
2.9\end{array}$ & $\begin{array}{l}1.10 \\
0.38\end{array}$ & $\begin{array}{r}6.9 \\
12.5 \\
1.02 \\
3.0\end{array}$ & $\begin{array}{r}10.5 \\
9.2 \\
3.7 \\
4.5\end{array}$ & $\begin{array}{r}5.6 \\
7.8 \\
1.65 \\
3.8\end{array}$ & $\begin{array}{l}7.7 \\
7.4 \\
1.4 \\
2.7\end{array}$ & $\begin{array}{r}0.87 \\
\pm 0.28 \\
0.54 \\
\pm 0.22\end{array}$ \\
\hline
\end{tabular}

* Low data coverage. See Sect. 2.1.

$N_{6-100}$ concentrations over the next morning. This affected the baseline if a non-nucleation day followed a nucleation day, and, particularly, in the seasons when NPF events occur well separated from each other in time, which is typical for winter. The elevated baseline is a real effect of the NPF, and it should definitely be included when deriving the mean $\mathrm{NSF}_{\mathrm{NUC}}$.

It was also observed in all years that the concentration increment on nucleation days due to NPF (i.e. $\mathrm{NSF}_{\mathrm{GEN}}$ ) was largest for winter. This evidently showed up for the near-city background. It was followed by the other seasons which had similar importance to each other in the city centre, or which were ordered as spring, autumn and summer in the near-city background. To investigate these findings more closely, diurnal variations of the related particle number concentrations were derived and evaluated. Diurnal variations of the concentrations for summer and winter are shown in Figs. 2 and 3 , respectively, for the city centre and near-city background. The dependencies in the city centre for the spring, autumn and summer seasons are similar to Fig. 2a, while the corresponding seasonal curves for the near-city background resemble Fig. 2b. The diurnal patterns represented by Fig. 2 are coherent with previous ideas on the NPF and growth events in the Budapest area (Salma et al., 2014, 2016b; Németh et al., 2017). They also confirm the basic assumptions of the
$\mathrm{NSF}_{\mathrm{NUC}}$ definition about the source intensities at both location types. The comparison of the $N_{6-100}$ curves for nucleation days and non-nucleation days already emphasizes the importance of NPF, and indicates that the phenomenon has a larger relative effect in the near-city background than in the central urban parts - as is expected. The late evening peak can likely be related to the combined effect of burning activities at residences and homes, and local meteorology, and they are also influenced by the daily cycling of the boundary layer mixing height and mixing intensity. As far as the $N_{6-100}$ between 06:00 and 09:00 is concerned, its higher level on non-nucleation days with respect to nucleation days is related to the higher pre-existing aerosol concentration level, and, thus, to large condensation sink values, which hinder NPF. The $N_{100-1000}$ curves appear close to each other within a relative uncertainty of $10-20 \%$, which implies that the accumulation-mode concentrations affect the NPF occurrence and formation rate in a limited manner in these seasons.

For winter, it is seen, however, that the $N_{100-1000}$ were substantially different for the nucleation and non-nucleation days (Fig. 3). The mean non-nucleation and nucleation $N_{100-1000}$ ratios for the city centre (in 2008-2009) and the near-city background were 2.8 and 2.3 , respectively. This implies that the NPF events preferably took place on those 

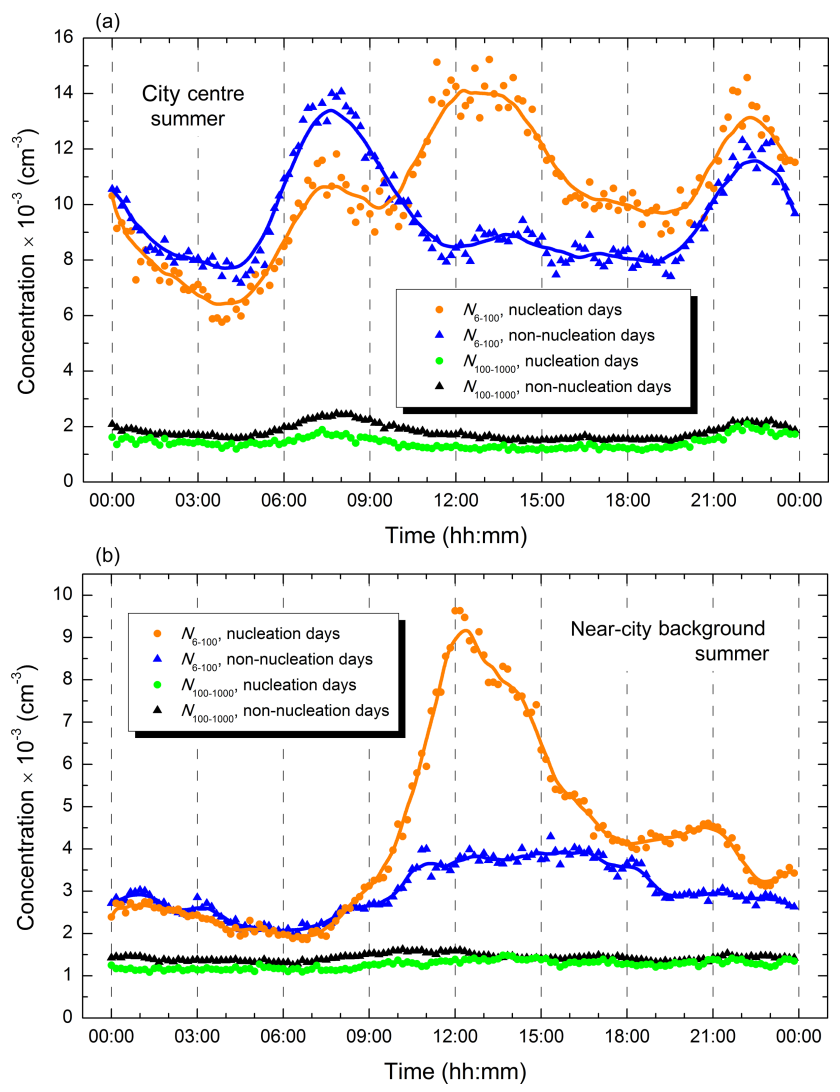

Figure 2. Diurnal variation of particle number concentrations in summer for the diameter ranges from 6 to $100 \mathrm{~nm}\left(N_{6-100}\right)$ and from 100 to $1000 \mathrm{~nm}\left(N_{100-1000}\right)$ in the city centre in 20082009 (a) and in the near-city background in 2012-2013 (b) separately for nucleation days and non-nucleation days. The solid lines represent $1 \mathrm{~h}$ smoothing of the data.

days when the particle number concentrations were generally smaller. It is understandable if we consider that the basic preconditions of NPF events are realized by competing sources and sinks for condensing vapours. The source strength in winter has a decreased tendency due to lower solar radiation intensities and fewer (biogenic) precursor gases in the air. There is indirect evidence that biogenic emissions contribute to the early stage of the growth process, and, likely, to the nucleation itself as well (Salma et al., 2016b). Nevertheless, nucleation can occur at these small source terms if the (condensation and scavenging) sink - which is related to the concentration of pre-existing particles - is even smaller. This explains the differences in the $N_{100-1000}$ on nucleation and non-nucleation days. Larger concentration increments (higher $\mathrm{NSF}_{\mathrm{NUC}}$, Fig. 3) for winter were simply caused by systematically smaller $N_{100-1000}$ on nucleation days. In addition, the fluctuation in this concentration for nucleation days in the winters of the other years was sometimes larger than that shown in Fig. 3. This observation raises the question of the smallest number of NPF events in a time inter-
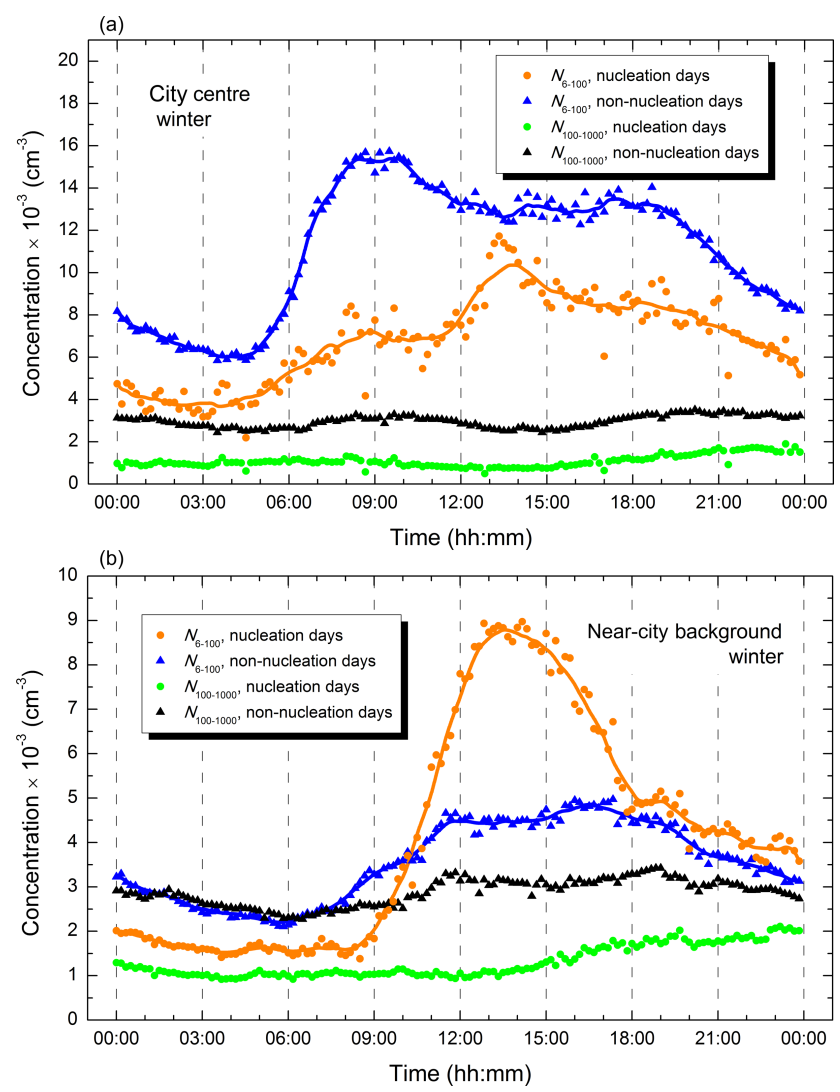

Figure 3. Diurnal variation of particle number concentrations in winter for the diameter ranges from 6 to $100 \mathrm{~nm}\left(N_{6-100}\right)$ and from 100 to $1000 \mathrm{~nm}\left(N_{100-1000}\right)$ in the city centre in 2008-2009 (a) and in the near-city background in 2012-2013 (b) separately for nucleation days and non-nucleation days. The solid lines represent $1 \mathrm{~h}$ smoothing of the data.

val (e.g. season) that is sufficient for obtaining representative $\mathrm{NSF}_{\mathrm{NUC}}$. A few NPF events during winters (see Table 1) may not be fully satisfactory for this purpose. The longer time intervals needed do not detract from the value of the quantification, because the health and environmental effects of NPF are important mostly on longer timescales.

Seasonal and annual mean concentration increments on a nucleation day (i.e. the daily mean $\mathrm{NSF}_{\mathrm{NUC}}$ values) for different years are summarized in Table 3. Nucleation as a single source increased the daily particle number concentrations by factors of 2.3 and 1.58 in the near-city background and city centre, respectively, on an annual timescale. The differences among the annual mean values, and among the corresponding seasonal mean values, were likely caused by the variability of controlling parameters from year to year. As far as the seasonal variation is concerned, it is noted that the formation rate for particles with a diameter of $6 \mathrm{~nm}\left(J_{6}\right)$ showed only limited seasonal dependency in Budapest (Salma et al., 2011), which also contributes to similar mean increments for spring, summer and autumn. 
Table 3. Seasonal and annual mean increments of $N_{100-1000}$ due to nucleation on a nucleation day (nucleation strength factor NSF NUC $_{\text {) in }}$ the near-city background (in 2012-2013) and in the city centre (in 2008-2009, 2013-2014, 2014-2015 and 2015-2016) during 1-year long time intervals.

\begin{tabular}{lrrrrrr}
\hline \multirow{2}{*}{ Urban environment } & Time interval & \multicolumn{5}{c}{ NSF NUC } \\
\cline { 3 - 7 } & & Spring & Summer & Autumn & Winter & Year \\
\hline Background & $2012-2013$ & 2.3 & 1.66 & 2.2 & 3.0 & 2.3 \\
Centre & $2008-2009$ & 1.36 & 1.55 & 1.42 & 1.71 & 1.49 \\
Centre & $2013-2014$ & 1.31 & 1.33 & 1.36 & 1.56 & 1.44 \\
Centre & $2014-2015$ & 1.50 & 1.34 & 1.83 & 2.8 & 1.73 \\
Centre & $2015-2016$ & 1.54 & 1.26 & 1.46 & 2.4 & 1.64 \\
\hline
\end{tabular}

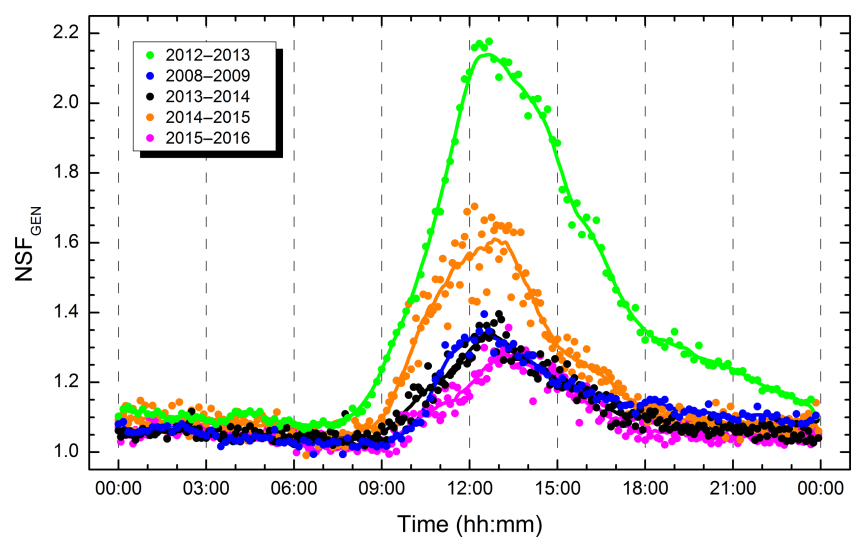

Figure 4. Diurnal variation of NPF contributions to particle number concentrations $\left(\mathrm{NSF}_{\mathrm{GEN}}\right.$ ) in the near-city background (in 20122013) and in the city centre (in 2008-2009, 2013-2014, 2014-2015 and 2015-2016) during 1-year long time intervals. The solid lines represent $1 \mathrm{~h}$ smoothing of the data.

\subsection{Contribution of nucleation to particle number concentrations}

Diurnal variation of $\mathrm{NSF}_{\mathrm{GEN}}$ is shown in Fig. 4. The curves exhibited a single peak with a maximum around noon and a longer tail in the early afternoon. The maximum values in the city centre represented concentration contributions from 30 to $60 \%$ due to nucleation for a limited time interval. The curve for the near-city background was the largest, as expected, and it even exceeded the value of 2 around noon for approximately $3 \mathrm{~h}$. This all means that nucleation has an important contribution to UF particles during the midday in the city centre, while it even becomes the dominant source of particles directly after midday in the near-city background.

The importance of nucleation was also demonstrated for different seasons and years by the mean $\mathrm{NSF}_{\mathrm{GEN}}$ values which are summarized in Table 4. In general, at least $37 \%$ of UF particles (more precisely of particle number increase) were produced by nucleation as a single source in the nearcity background. In the city centre, it generated at least $13 \%$ of UF particles. The values are considered lower limits since a considerable number of $N_{100-1000}$ particles can also be produced by NPF from previous days. Nevertheless, the proposed method is capable of quantifying the relevance of particles from NPF relative to other sources for the first time, which is an unambiguous and important step forward in urban atmospheric studies. The differences among the annual mean values, and among the corresponding seasonal mean values, were likely caused by the year-to-year variability, similarly to the concentration increments on nucleation days ( $\mathrm{NSF}_{\mathrm{NUC}}$ ). It is informative to compare the contribution values to the global share of various source sectors in primary UF particle number emission to have an idea of the relative extent of our results. It is stressed that our and the literature data are related to very different types of particles; nevertheless, some analogy can be found in the relative importance of the sources and source processes. Road transport, power production and residential combustion are the first three largest contributors to primary UF particles, with shares of 40, 20 and $17 \%$, respectively (Paasonen et al., 2016). The actual contributions can vary in different parts of the world and with economic development.

The effects of particles generated by NPF and growth in increased concentrations on human health and the environment are also influenced by the time interval for which the particles remain in the air. Nucleation-mode particles are primarily removed by coagulation with larger particles, agglomeration, diffusion and turbulent losses, scavenging and various aging processes. We showed in Sect. 3.2 and it can also be proven directly from the measured data that it is the NPF events that usually produce the $N_{6-25}$ concentrations to an overwhelming extent (the $N_{6-25}$ is increased by $1-2$ orders of magnitude) in a relatively short time interval. The continual concentration decrease in time for several hours after the event can be utilized to assess the general atmospheric residence time of nucleation-mode particles. The decrease in this concentration after a nucleation burst could be approximated by an exponential function (first-order kinetics). By a decay curve analysis of 15 selected NPF and particle diameter growth cases, the residence times were estimated from the slope of the concentrations $N_{6-25}$ in a natural logarith- 


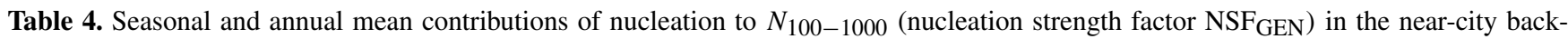
ground (in 2012-2013) and in the city centre (in 2008-2009, 2013-2014, 2014-2015 and 2015-2016) during 1-year long time intervals.

\begin{tabular}{lrrrrrr}
\hline \multirow{2}{*}{ Urban environment } & Time interval & \multicolumn{5}{c}{ NSF $_{\text {GEN }}$} \\
\cline { 3 - 7 } & & Spring & Summer & Autumn & Winter & Year \\
\hline Background & $2012-2013$ & 1.51 & 1.18 & 1.31 & 1.40 & 1.37 \\
Centre & $2008-2009$ & 1.12 & 1.15 & 1.10 & 1.05 & 1.12 \\
Centre & $2013-2014$ & 1.11 & 1.07 & 1.08 & 1.11 & 1.11 \\
Centre & $2014-2015$ & 1.22 & 1.08 & 1.14 & 1.16 & 1.19 \\
Centre & $2015-2016$ & 1.09 & 1.06 & 1.03 & 1.09 & 1.09 \\
\hline
\end{tabular}

mic scale versus time. The residence time of nucleated particles varied from 01:30 to 04:15 with a mean and SD of 02:30 $\pm 01: 00$. This suggests that the nucleation-mode particles (more exactly the nucleated particles in their very small sizes) are expected to have limited health effects due to their relatively short existence in the air, although there is little experimental information available on the chemical composition and health effects of nucleated nanoparticles.

\section{Conclusions}

We showed in the present study that NPF and a particle diameter growth process as a single source represent a considerable contribution to UF particles in a central European city with respect to all other emission sources, including vehicular road traffic. Nucleation was a major process that produced UF particles at noon and in the early afternoon, and its relative contribution was comparable to other production sources during this time period, even in the city centre. The relative importance of nucleation as a source of particles decreased with anthropogenic influence. The NSFs were defined by utilizing $N_{6-100}$ and $N_{100-1000}$ concentrations. There are several sensible and practical reasons for selecting these specific size fractions, although other dividing values are also imaginable. The quantifications in the present study are, therefore, subject to a certain inherent uncertainty. Considering that the modes of the particle number size distribution are usually shifted to smaller diameters in cities with respect to rural or remote areas, it seems realistic that these size fractions will represent well the particles of urban (local) origin and the aged particles (which characterize larger spatial or urban background areas), respectively. The study also suggests that particles from NPF events in cities are relevant not only for their effects on urban climate, but also because of their health risk to inhabitants. At the same time, it should also be mentioned that ambient atmospheric aerosol, which ordinarily persists in the air of cities, contains particles in the largest abundance, with a diameter of between approximately 25 and $150 \mathrm{~nm}$. The atmospheric aerosol system containing smaller particles is thermodynamically not stable, and most of these particles are removed from the air during relatively short time intervals. The exposures to freshly nucleated particles $(d<25 \mathrm{~nm})$ or ambient nanoparticles $(d<10 \mathrm{~nm})$ are usually limited to several hours after the onset of the NPF.

Regulations of aerosol emissions and atmospheric concentrations are usually based on PM mass. The changes or reductions in anthropogenic aerosol load are ordinarily assessed by assuming similar relative tendencies in particle mass and particle number concentrations. This generalization may yield tentative conclusions. According to current legislation scenarios, particle number emissions are expected to decrease in most parts of the world by 2030, mainly due to spreading the diesel particulate filters (DPFs) in cars and due to diesel fuels with an ultralow sulfur content. In effect, this may imply that the relative share of NPF in the particle number production is expected to increase above the levels estimated in the present study. By demonstrating the relevance of NPF as an important single source of UF particles, we also raise the question of an international enhanced particle mass and particle number inventory with precursor gas data that potentially includes the NPF and the growth process as a separate sector among the source types.

Data availability. The relevant observational data used in this paper are available on request from the corresponding author or at the website of the Budapest platform for Aerosol Research and Training (http://salma.web.elte.hu/BpArt).

Competing interests. The authors declare that they have no conflict of interest.

Acknowledgements. Financial support by the National Research, Development and Innovation Office of Hungary (contract K116788) is appreciated.

Edited by: Kari Lehtinen

Reviewed by: two anonymous referees 


\section{References}

Alam, A., Shi, J. P., and Harrison, R. M.: Observation of new particle formation in urban air, J. Geophys. Res., 108, 4093-4107, 2003.

Braakhuis, H. M., Park, M. V., Gosens, I., De Jong, W. H., and Cassee, F. R.: Physicochemical characteristics of nanomaterials that affect pulmonary inflammation, Part, Fibre Toxicol., 11, 18, https://doi.org/10.1186/1743-8977-11-18, 2014.

Brines, M., Dall'Osto, M., Beddows, D. C. S., Harrison, R. M., Gómez-Moreno, F., Núñez, L., Artíñano, B., Costabile, F., Gobbi, G. P., Salimi, F., Morawska, L., Sioutas, C., and Querol, X.: Traffic and nucleation events as main sources of ultrafine particles in high-insolation developed world cities, Atmos. Chem. Phys., 15, 5929-5945, https://doi.org/10.5194/acp15-5929-2015, 2015.

Butt, E. W., Rap, A., Schmidt, A., Scott, C. E., Pringle, K. J., Reddington, C. L., Richards, N. A. D., Woodhouse, M. T., RamirezVillegas, J., Yang, H., Vakkari, V., Stone, E. A., Rupakheti, M. S., Praveen, P. G., van Zyl, P. P., Beukes, J., Josipovic, M., Mitchell, E. J. S., Sallu, S. M., Forster, P. M., and Spracklen, D. V.: The impact of residential combustion emissions on atmospheric aerosol, human health, and climate, Atmos. Chem. Phys., 16, 873-905, https://doi.org/10.5194/acp-16-873-2016, 2016.

Carslaw, K. S., Lee, L. A., Reddington, C. L., Pringle, K. J., Rap, A., Forster, P. M., Mann, G. W., Spracklen, D. V., Woodhouse, M. T., Regayre, L. A., and Pierce, J. R.: Large contribution of natural aerosols to uncertainty in indirect forcing, Nature, 503, 67-71, 2013.

Costabile, F., Birmili, W., Klose, S., Tuch, T., Wehner, B., Wiedensohler, A., Franck, U., König, K., and Sonntag, A.: Spatiotemporal variability and principal components of the particle number size distribution in an urban atmosphere, Atmos. Chem. Phys., 9, 3163-3195, https://doi.org/10.5194/acp-9-3163-2009, 2009.

Dal Maso, M., Kulmala, M., Riipinen, I., Wagner, R., Hussein, T., Aalto, P. P., and Lehtinen, K. E. J.: Formation and growth of fresh atmospheric aerosols: eight years of aerosol size distribution data from SMEAR II, Hyytiälä, Finland, Boreal Environ. Res., 10, 323-336, 2005.

Dall'Osto, M., Querol, X., Alastuey, A., O'Dowd, C., Harrison, R. M., Wenger, J., and Gómez-Moreno, F. J.: On the spatial distribution and evolution of ultrafine particles in Barcelona, Atmos. Chem. Phys., 13, 741-759, https://doi.org/10.5194/acp-13-7412013, 2013.

Kerminen, V.-M., Paramonov, M., Anttila, T., Riipinen, I., Fountoukis, C., Korhonen, H., Asmi, E., Laakso, L., Lihavainen, H., Swietlicki, E., Svenningsson, B., Asmi, A., Pandis, S. N., Kulmala, M., and Petäjä, T.: Cloud condensation nuclei production associated with atmospheric nucleation: a synthesis based on existing literature and new results, Atmos. Chem. Phys., 12, 12037 12059, https://doi.org/10.5194/acp-12-12037-2012, 2012.

Kulmala, M., Vehkamäki, H., Petäjä, T., Dal Maso, M., Lauri, A., Kerminen, V.-M., Birmili, W., and McMurry, P.: Formation and growth rates of ultrafine atmospheric particles: a review of observations, J. Aerosol Sci., 35, 143-176, 2004.

Kulmala, M., Petäjä, T., Nieminen, T., Sipilä, M., Manninen, H. E., Lehtipalo, K., Dal Maso, M., Aalto, P. P., Junninen, H., Paasonen, P., Riipinen, I., Lehtinen, K. E. J., Laaksonen, A., and Kerminen, V.-M.: Measurement of the nucleation of atmospheric aerosol particles, Nat. Protoc., 7, 1651-1667, https://doi.org/10.1038/nprot.2012.091, 2012.

Kulmala, M., Kontkanen, J., Junninen, H., Lehtipalo, K., Manninen, H. E., Nieminen, T., Petäjä, T., Sipilä, M., Schobesberger, S., Rantala, P., Franchin, A., Jokinen, T., Järvinen, E., Äijälä, M., Kangasluoma, J., Hakala, J., Aalto, P. P., Paasonen, P., Mikkilä, J., Vanhanen, J., Aalto, J., Hakola, H., Makkonen, U., Ruuskanen, T., Mauldin III, R. L., Duplissy, J., Vehkamäki, H., Bäck, J., Kortelainen, A., Riipinen, I., Kurtén, T., Johnston, M. V., Smith, J. N., Ehn, M., Mentel, T. F., Lehtinen, K. E. J., Laaksonen, A., Kerminen, V.-M., and Worsnop, D. R.: Direct observations of atmospheric aerosol nucleation, Science, 339, 943-946, 2013.

Makkonen, R., Asmi, A., Kerminen, V.-M., Boy, M., Arneth, A., Hari, P., and Kulmala, M.: Air pollution control and decreasing new particle formation lead to strong climate warming, Atmos. Chem. Phys., 12, 1515-1524, https://doi.org/10.5194/acp12-1515-2012, 2012.

Manninen, H. E., Nieminen, T., Asmi, E., Gagné, S., Häkkinen, S., Lehtipalo, K., Aalto, P., Vana, M., Mirme, A., Mirme, S., Hõrrak, U., Plass-Dülmer, C., Stange, G., Kiss, G., Hoffer, A., Töro, N., Moerman, M., Henzing, B., de Leeuw, G., Brinkenberg, M., Kouvarakis, G. N., Bougiatioti, A., Mihalopoulos, N., O’Dowd, C., Ceburnis, D., Arneth, A., Svenningsson, B., Swietlicki, E., Tarozzi, L., Decesari, S., Facchini, M. C., Birmili, W. Sonntag, A., Wiedensohler, A., Boulon, J., Sellegri, K., Laj, P., Gysel, M., Bukowiecki, N., Weingartner, E., Wehrle, G., Laaksonen, A., Hamed, A., Joutsensaari, J., Petäjä, T., Kerminen, V.-M., and Kulmala, M.: EUCAARI ion spectrometer measurements at 12 European sites - analysis of new particle formation events, Atmos. Chem. Phys., 10, 7907-7927, https://doi.org/10.5194/acp10-7907-2010, 2010.

Merikanto, J., Spracklen, D. V., Mann, G. W., Pickering, S. J., and Carslaw, K. S.: Impact of nucleation on global CCN, Atmos. Chem. Phys., 9, 8601-8616, https://doi.org/10.5194/acp-9-86012009, 2009.

Morawska, L., Ristovski, Z., Jayaratne, E. R., Keogh, D. U., and Ling, X.: Ambient nano and ultrafine particles from motor vehicle emissions: characteristics, ambient processing and implications on human exposure, Atmos. Environ., 42, 8113-8138, 2008.

Németh, Z., Rosati, B., Zíková, N., Salma, I., Bozó, L., Dameto de España, C., Schwarz, J., Ždímal, V., and Wonaschütz, A.: Comparison of atmospheric new particle formation and growth events in three Central European cities, submitted, 2017.

Nieminen, T., Kerminen, V.-M., Petäjä, T., Manninen, H. E., Aalto, P. P., Arshinov, M., Asmi, E., Baltensberger, U., Beukes, J. P., Collins, D., Harrison, R. M., Henzing, B., Hooda, R., Hu, M., Hõrrak, U., Kivekäs, N., Komsaare, K., Krejčí, R., Laakso, L., Laaksonen, A., Leaitch, R., Lihavainen, H., Mihalopoulos, N., Németh, Z., O’Dowd, C., Salma, I., Sellegri, K., Svenningsson, B., Swietlicki, E., Tunved, P., Ulevicius, V., Vakkari, V., Vana, M., Virtanen, A., Wiedensohler, A., and Kulmala, M.: Global analysis of continental boundary layer new particle formation based on long-term measurements, Atmos. Chem. Phys. Discuss., in preparation, 2017.

Oberdörster, G., Oberdörster, E., and Oberdörster, J.: Nanotoxicology: an emerging discipline evolving from studies of ultrafine particles, Environ. Health Persp., 113, 823-839, 2005. 
OKJ: National register of road vehicles, Ministry of National Development, Budapest, 2015 (in Hungarian).

Paasonen, P., Kupiainen, K., Klimont, Z., Visschedijk, A., Denier van der Gon, H. A. C., and Amann, M.: Continental anthropogenic primary particle number emissions, Atmos. Chem. Phys., 16, 6823-6840, https://doi.org/10.5194/acp-166823-2016, 2016.

Park, K., Park, J. Y., Kwak, J.-H., Cho, G. N., and Kim, J.-S.: Seasonal and diurnal variations of ultrafine particle concentration in urban Gwangju, Korea: Observation of ultrafine particle events, Atmos. Environ., 42, 788-799, 2008.

Pikridas, M., Sciare, J., Freutel, F., Crumeyrolle, S., von der Weiden-Reinmüller, S.-L., Borbon, A., Schwarzenboeck, A., Merkel, M., Crippa, M., Kostenidou, E., Psichoudaki, M., Hildebrandt, L., Engelhart, G. J., Petäjä, T., Prévôt, A. S. H., Drewnick, F., Baltensperger, U., Wiedensohler, A., Kulmala, M., Beekmann, M., and Pandis, S. N.: In situ formation and spatial variability of particle number concentration in a European megacity, Atmos. Chem. Phys., 15, 10219-10237, https://doi.org/10.5194/acp-15-10219-2015, 2015.

Posner, L. N. and Pandis, S. N.: Sources of ultrafine particles in the Eastern United States, Atmos. Environ., 111, 103-112, 2015.

Putaud, J.-P., Van Dingenen, R., Alastuey, A., Bauer, H., Birmili, W., Cyrys, J., Flentje, H., Fuzzi, S., Gehrig, R., Hansson, H. C., Harrison, R. M., Herrmann, H., Hitzenberger, R., Hüglin, C., Jones, A. M., Kasper-Giebl, A., Kiss, G., Kousa, A., Kuhlbusch, T. A. J., Löschau, G., Maenhaut, W., Molnár, A., Moreno, T., Pekkanen, J., Perrino, C., Pitz, M., Puxbaum, H., Querol, X., Rodriguez, S., Salma, I., Schwarz, J., Smolik, J., Schneider, J., Spindler, G., ten Brink, H., Tursic, J., Viana, M., Wiedensohler, A., and Raes, F.: A European Aerosol Phenomenology - 3: physical and chemical characteristics of particulate matter from 60 rural, urban, and kerbside sites across Europe, Atmos. Environ., 44, 1308-1320, 2010.

Qian, S., Sakurai, H., and McMurry, P. H.: Characteristics of regional nucleation events in urban East St. Louis, Atmos. Environ., 41, 4119-4127, 2007.

Reddington, C. L., Carslaw, K. S., Spracklen, D. V., Frontoso, M. G., Collins, L., Merikanto, J., Minikin, A., Hamburger, T., Coe, H., Kulmala, M., Aalto, P., Flentje, H., Plass-Dülmer, C., Birmili, W., Wiedensohler, A., Wehner, B., Tuch, T., Sonntag, A., O’Dowd, C. D., Jennings, S. G., Dupuy, R., Baltensperger, U., Weingartner, E., Hansson, H.-C., Tunved, P., Laj, P., Sellegri, K., Boulon, J., Putaud, J.-P., Gruening, C., Swietlicki, E., Roldin, P., Henzing, J. S., Moerman, M., Mihalopoulos, N., Kouvarakis, G., Ždímal, V., Zíková, N., Marinoni, A., Bonasoni, P., and Duchi, R.: Primary versus secondary contributions to particle number concentrations in the European boundary layer, Atmos. Chem. Phys., 11, 12007-12036, https://doi.org/10.5194/acp-11-120072011, 2011.

Rodríguez, S. and Cuevas, E.: The contributions of "minimum primary emissions" and "new particle formation enhancements" to the particle number concentration in urban air, J. Aerosol Sci., 38, 1207-1219, 2007.

Salma, I., Borsós, T., Weidinger, T., Aalto, P., Hussein, T., Dal Maso, M., and Kulmala, M.: Production, growth and properties of ultrafine atmospheric aerosol particles in an urban environment, Atmos. Chem. Phys., 11, 1339-1353, https://doi.org/10.5194/acp-11-1339-2011, 2011.
Salma, I., Borsós, T., Németh, Z., Weidinger, T., Aalto, P., and Kulmala, M.: Comparative study of ultrafine atmospheric aerosol within a city, Atmos. Environ., 92, 154-161, 2014.

Salma, I., Németh, Z., Weidinger, T., Kovács, B., and Kristóf, G.: Measurement, growth types and shrinkage of newly formed aerosol particles at an urban research platform, Atmos. Chem. Phys., 16, 7837-7851, https://doi.org/10.5194/acp16-7837-2016, $2016 \mathrm{a}$.

Salma, I., Németh, Z., Kerminen, V.-M., Aalto, P., Nieminen, T., Weidinger, T., Molnár, Á., Imre, K., and Kulmala, M.: Regional effect on urban atmospheric nucleation, Atmos. Chem. Phys., 16, 8715-8728, https://doi.org/10.5194/acp-16-8715-2016, $2016 \mathrm{~b}$.

Salma, I., Németh, Z., Weidinger, T., Maenhaut, W., Claeys, M., Molnár, M., Major, I., Ajtai, T., Utry, N., and Bozóki, Z.: Source apportionment of carbonaceous chemical species to fossil fuel combustion, biomass burning and biogenic emissions by a coupled radiocarbon-levoglucosan marker method, Atmos. Chem. Phys., 17, 13767-13781, https://doi.org/10.5194/acp-17-137672017, 2017.

Samoli, E., Andersen, Z. J., Katsouyanni, K., Hennig, F., Kuhlbusch, T. A. J., Bellander, T., Cattani, G., Cyrys, J., Forastiere, F., Jacquemin, B., Kulmala, M., Lanki, T., Loft, S., Massling, A., Tobias, A., and Stafoggia, M.: Exposure to ultrafine particles and respiratory hospitalisations in five European cities, Eur. Resp. J., 48, 674-682, 2016.

Shen, L., Mickley, L. J., and Murray, L. T.: Influence of 2000-2050 climate change on particulate matter in the United States: results from a new statistical model, Atmos. Chem. Phys., 17, 43554367, https://doi.org/10.5194/acp-17-4355-2017, 2017.

Shi, J. P., Khan, A. A., and Harrison, R. M.: Measurements of ultrafine particle concentration and size distribution in the urban atmosphere, Sci. Total Environ., 235, 51-64, 1999.

Spracklen, D. V., Carslaw, K. S., Kulmala, M., Kerminen, V.-M., Mann, G. W., and Sihto, S.-L.: The contribution of boundary layer nucleation events to total particle concentrations on regional and global scales, Atmos. Chem. Phys., 6, 5631-5648, https://doi.org/10.5194/acp-6-5631-2006, 2006.

Spracklen, D. V., Carslaw, K. S., Kulmala, M., Kerminen, V.-M., Sihto, S.-L., Riipinen, I., Merikanto, J., Mann, G. W., Chipperfield, M. P., Wiedensohler, A., Birmili, W., and Lihavainen, H.: Contribution of particle formation to global cloud condensation nuclei concentrations, Geophys. Res. Lett., 35, L06808, https://doi.org/10.1029/2007GL033038, 2008.

Wiedensohler, A., Birmili, W., Nowak, A., Sonntag, A., Weinhold, K., Merkel, M., Wehner, B., Tuch, T., Pfeifer, S., Fiebig, M., Fjäraa, A. M., Asmi, E., Sellegri, K., Depuy, R., Venzac, H., Villani, P., Laj, P., Aalto, P., Ogren, J. A., Swietlicki, E., Williams, P., Roldin, P., Quincey, P., Hüglin, C., Fierz-Schmidhauser, R., Gysel, M., Weingartner, E., Riccobono, F., Santos, S., Grüning, C., Faloon, K., Beddows, D., Harrison, R., Monahan, C., Jennings, S. G., O’Dowd, C. D., Marinoni, A., Horn, H.-G., Keck, L., Jiang, J., Scheckman, J., McMurry, P. H., Deng, Z., Zhao, C. S., Moerman, M., Henzing, B., de Leeuw, G., Löschau, G., and Bastian, S.: Mobility particle size spectrometers: harmonization of technical standards and data structure to facilitate high quality long-term observations of atmospheric particle number size distributions, Atmos. Meas. Tech., 5, 657-685, https://doi.org/10.5194/amt-5-657-2012, 2012. 
Xiao, S., Wang, M. Y., Yao, L., Kulmala, M., Zhou, B., Yang, X., Chen, J. M., Wang, D. F., Fu, Q. Y., Worsnop, D. R., and Wang, L.: Strong atmospheric new particle formation in winter in urban Shanghai, China, Atmos. Chem. Phys., 15, 1769-1781, https://doi.org/10.5194/acp-15-1769-2015, 2015.
Yu, F., Luo, G., Pryor, S. C., Pillai, P. R., Lee, S. H., Ortega, J., Schwab, J. J., Hallar, A. G., Leaitch, W. R., Aneja, V. P., Smith, J. N., Walker, J. T., Hogrefe, O., and Demerjian, K. L.: Spring and summer contrast in new particle formation over nine forest areas in North America, Atmos. Chem. Phys., 15, 13993-14003, https://doi.org/10.5194/acp-15-13993-2015, 2015. 